\title{
THE HEAT OF FORMATION OF SULPHUR DIOXIDE
}

\author{
By J. R. Eckman ${ }^{1}$ and Frederick D. Rossini
}

\section{ABSTRACT}

The heat of formation of sulphur dioxide has been redetermined. Since the burning of sulphur in excess oxygen results in the formation of varying small amounts of sulphur trioxide, which evolves some 90,000 more joules per mole in its formation than does sulphur dioxide, the difficulties involved in analyzing the combustion products for the trioxide and in making the corresponding corrections were obviated by the use of a specially designed calorimetric reaction chamber in which oxygen reacts with an excess of hot sulphur vapor to form pure sulphur dioxide. The heat of formation of sulphur dioxide at $25^{\circ} \mathrm{C}$. from rhombic sulphur and gaseous oxygen was found to be $+296,890 \pm 200$ absolute joules per mole.

\section{CONTENTS}

II. The reaction chamber and its operation

III. The chemical procedure

1. Preparation of the sulphur.... 601

2. Purification of the oxygen and the nitrogen

3. The analytical methods _....... 602

IV. The calorimetric apparatus and accessory instruments_._._._._. 603

1. The calorimeter........ 603

2. The thermometer

3. The electrical energy system .

V. Molecular weights, constants, factors, units, etc_._._._. 608

VI. The calorimetric procedure

1. Calibration experiments_... 609

2. Sulphur dioxide experiments _._. 612

VII. Results._._. 615

VIII. Summary

\section{INTRODUCTION}

The thermochemical data of J. Thomsen and M. Berthelot, who, working independently, laid the foundations of modern thermochemistry by their prodigious work of nearly half a century ago, are in many cases in good agreement. One striking exception to this consistency, however, occurs in the case of their results on the heat of formation of $\mathrm{SO}_{2}$. Berthelot ${ }^{2}$ reported a value of $+69,260$ calories

1 The bureau regrets to announce that since this paper was written Doctor Eckman has died.

2 M. Berthelot, Ann. de chim, et de phys., 22, p. 422; 1881. 
while Thomsen ${ }^{3}$ found $+71,080$ calories. The discrepancy is $2 \frac{1}{2}$ per cent. This difference is much greater than can be accounted for by the random errors in their calorimetric technic, and may be the result of some fault in the analytical methods.

Although their experimental methods were slightly different, both Thomsen and Berthelot burned the sulphur in an excess of oxygen. This resulted in the formation of varying small amounts of $\mathrm{SO}_{3}$ along with the $\mathrm{SO}_{2}$, and, since the heat of formation of $\mathrm{SO}_{3}$ is about 21,500 calories per mole greater than that of $\mathrm{SO}_{2}$, it was necessary to determine the exact amount of $\mathrm{SO}_{3}$ formed in each experiment so that the proper correction could be applied. Another possible correction to such experimentally determined heats is that for the heat of the reaction of the $\mathrm{SO}_{3}$ with water vapor from imperfectly dried oxygen or with moisture on the walls of the apparatus.

Thomsen and Berthelot did not agree as to the effectiveness of each other's analytical methods for determining the $\mathrm{SO}_{3}$ formed. Berthelot, ${ }^{4}$ in bis second report on the heat of formation of $\mathrm{SO}_{2}$, which appeared shortly after Thomsen ${ }^{5}$ had published his results, was of the opinion that Thomsen's higher value was due to the fact that his analytical method did not recover all the $\mathrm{SO}_{3}$ formed.

Berthelot ${ }^{4}$ quoted results by five earlier investigators. These included the following, in chronological order: Dulong, + 83,200; Hess, + 82,200; Favre and Silbermann, +71,200; Andrews, +73,800; Thomsen, +71,080; and finally Berthelot, $+69,260$ calories. The results of Dulong and of Hess are obviously much in error, since all the others are grouped within about 5 per cent of one another. In 1904, Giran reported a value of 69,800 calories. $^{6}$

Before attempting a new calorimetric determination of the heat of this reaction there were two problems to solve. The first of these was the development of a sufficiently exact method for determining small amounts of $\mathrm{SO}_{3}$ in $\mathrm{SO}_{2}$. The solution of this problem is reported in a previous paper by one of the authors. ${ }^{7}$ The methed consists, briefly, in condensing the $\mathrm{SO}_{3}$ from the $\mathrm{SO}_{2}$, dissolving it in an oxygen-free aqueous solution of $\mathrm{BaSO}_{3}$, and weighing the precipitated $\mathrm{BaSO}_{4}$. The second problem involved the development of a satisfactory calorimetric reaction chamber in which the union of sulphur and oxygen could be made to take place with the formation of a minimum amount of $\mathrm{SO}_{3}$.

${ }^{3}$ J. Thomsen, Thermochemische Untersuchungen, J. A. Barth, Leipzig; 1882. Berichte, 13A, p. 959; 1880.

${ }^{4}$ See footnote 2, p. 597.

5 See footnote 2, p. 597.

${ }^{6}$ H. Giran, Compt. rend., 139, p. 1219; 1904; 149, p. 1704; 1905. With a bomb calorimeter Giran found. that the apparent heat of formation of 1 mole of $\mathrm{SO}_{2}$, after correction for the formation of $\mathrm{SO}_{3}$, increased with increase in the pressure of the oxygen in the bomb. He offered as an explanation for this the formation of $\mathrm{H}_{2} \mathrm{SO}_{4} . \mathrm{SO}_{3}$ from the reaction of $\mathrm{SO}_{3}$ with the small amount of water vapor present in the bomb.

7 J. R. Eckman, B. S. Sci. Paper No. 554, 22, p. 277; 1927. 


\section{THE REACTION CHAMBER AND ITS OPERATION}

The fundamental idea underlying the design and construction of the reaction chamber was the introduction of oxygen gas into an excess of hot sulphur vapor, in order to minimize the formation of $\mathrm{SO}_{3}{ }^{8}$ After preliminary experiments with various types, the reaction chamber shown in Figure 1 was developed. In this reaction chamber, sulphur is converted into $\mathrm{SO}_{2}$ without the formation of any detectable amounts of $\mathrm{SO}_{3}$ when tested by the analytical method described above.

The reaction chamber was made entirely of pyrex glass with the exception of the platinum wire used to supply electrical energy to the chamber and the platinum tip on the inlet tube.

The procedure einployed in carrying out the reaction, with the chamber immersed in the water of the calorimeter, was as follows: About $8 \mathrm{~g}$ of pure rhombic sulphur, broken up into very small pieces, was introduced into the space $C$ through the entry tube $D$. The close-fitting ground-glass cap at $D$ was sealed with de Khotinsky cement. Pure dry nitrogen gas was passed through the reaction chamber, entering at $L$ and leaving at $M$, until all the space in the chamber was filled with nitrogen. Then an electric current was sent through the platinum wire. The heat developed melted all of the sulphur and vaporized part of it. The energy required to accomplish this totaled about 4,800 joules, over a period of four minutes. Onehalf minute before the current was cut off, the flow of pure dry

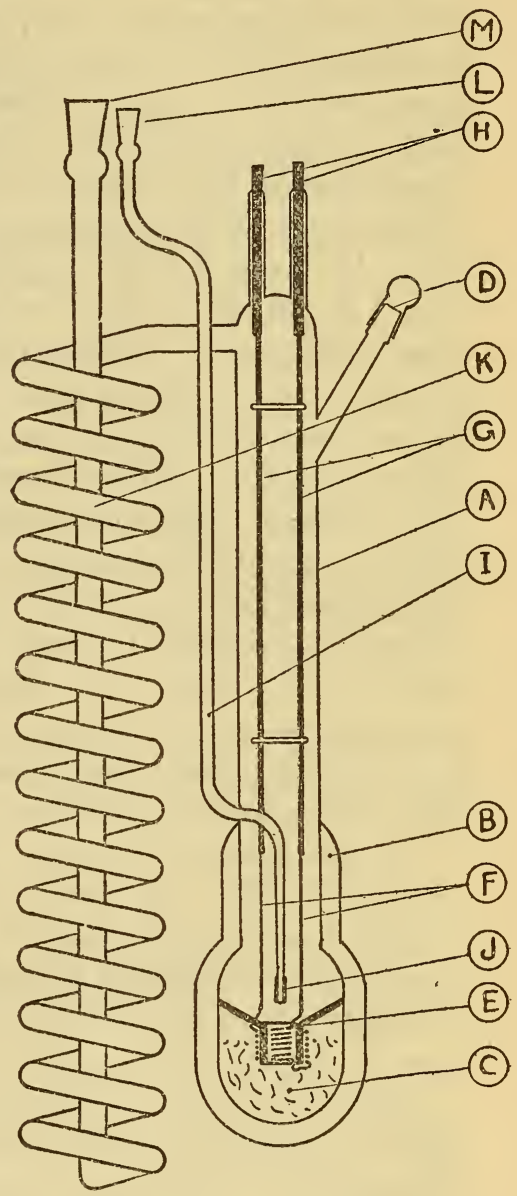

FIgURE 1.-The reaction chamber

$A$, body; $B$, vacuum jacket; $C$, space containing the sulphur which is filled in through the tube $D ; E$, open cylindrical tube, with supports to wall, for carrying the heating coil of platinum wire; $F$, No. 29 platinum wire; $G$, No. 18 platinum wire; $H$, No. 14 platinum wire; $I$, gas inlet tube with platinum tip $J$; $K$, coil for cooling exit gases; $L$ and $M$ ground glass connections. Over-all length is $24 \mathrm{~cm}$ oxygen gas into the chamber through $L$ was started. When the oxygen came in contact with the hot sulphur vapor, the formation

8 This method of preparing $\mathrm{SO}_{2}$ has been used by Randall and Bichowsky, J. Am. Chem. Soc., 40, p. $368 ; 1918$. 
of $\mathrm{SO}_{2}$ commenced. The visible evidence of this reaction was a blue-green region several centimeters long at $J$. The $\mathrm{SO}_{2}$ escaped from the body of the chamber into the cooling coil and passed through the exit $M$ into an absorber. When a sufficient amount of sulphur had been converted into $\mathrm{SO}_{2}$, the flow of oxygen was stopped and pure dry nitrogen gas was passed through the system. This served to remove all the $\mathrm{SO}_{2}$, and to help cool the chamber with its remaining: small amount of liquid sulphur by conducting heat energy to the water of the calorimeter. Temperature measurements of the exit gases showed that they were cooled, within $0.1^{\circ}$ or $0.2^{\circ} \mathrm{C}$., to the temperature of the calorimeter in their passage through the cooling coil. An error of $0.2^{\circ} \mathrm{C}$. in this measurement makes a difference of only 1 in 50,000 in the final result. The temperature of the platinum heating coil, as determined from its resistance just before the current was cut off, was in the neighborhood of $500^{\circ} \mathrm{C}$., and the temperature of the flame or reaction region proper must have been higher than this. The purpose of the platinum tip $J$ was to prevent the possible closing of the inlet tube by the sealing action of the flame. Except a slight discoloration, no evidence of any reaction of platinum with the sulphur was observed.

The flow of gases through the system carried some sulphur vapor out into the cooling coil. Most of this condensed in the coil, but some sulphur dust tended to remain in the gas stream. To prevent possible loss of sulphur from the system, several inches of the exit tube was filled with ground pyrex glass.

The few grams of sulphur which remained in the space $C$ quickly solidified when the reaction was stopped, and most of the sulphur had changed back to the rhombic form within 30 minutes. A calculation described in section 2, Part VI, of this paper indicates that only a very small part of the sulphur remained in the monoclinic form at the end of the experiment.

The system at the end of the experiment was in the same condition as at the beginning, except that all but a few grams of the sulphur had disappeared. The heat energy resulting from the conversion of this sulphur into $\mathrm{SO}_{2}$ had raised the temperature of the calorimeter several degrees.

Quantitative tests showed that no $\mathrm{SO}_{3}$ was formed when the reaction was carried out with an oxygen flow ranging from 0.05 to 0.15 liter per minute. In one test, $\mathrm{SO}_{3}$ vapor was purposely introduced into the reaction chamber with the oxygen gas and must have been there reduced to $\mathrm{SO}_{2}$ since no $\mathrm{SO}_{3}$ could be detected in the exit gases. 


\section{THE CHEMICAL PROCEDURE}

\section{PREPARATION OF THE SULPHUR}

The first step in the preparation of the pure sulphur for this investigation was its precipitation from an aqueous solution of $\mathrm{Na}_{2} \mathrm{~S}_{2} \mathrm{O}_{3}$ with $\mathrm{HCl}$. Crystallized $\mathrm{Na}_{2} \mathrm{~S}_{2} \mathrm{O}_{3} \cdot 5 \mathrm{H}_{2} \mathrm{O}$ was dissolved in twice its weight of water and an equivalent amount of concentrated $\mathrm{HCl}$ solution was added with constant stirring. When most of the sulphur had settled, the supernatant liquid was poured off and the sulphur was filtered out by suction on a porous porcelain plate in a Büchner funnel. The sulphur was then repeatedly washed with distilled water.

After drying, this sulphur was transferred to one of three pyrex flasks sealed in series so as to constitute a double glass still. The last traces of water were removed by heating the sulphur in flask 1 for some time below its melting point and removing the vapors with a vacuum pump. The sulphur was then melted and distilled, in vacuo, into flask 2 , and then from flask 2 to llask 3 . In the line between the last flask and the pump was a tube containing $\mathrm{P}_{2} \mathrm{O}_{5}$. This sulphur was then broken up into small pieces, placed in another multiple still, and redistilled four times in vacuo. The final pure sulphur was stored in a desiccator containing $\mathrm{P}_{2} \mathrm{O}_{5}$ and an atmosphere of pure nitrogen.

The liquid obtained by leaching several samples of this sulphur with warm water was tested ${ }^{9}$ for both sulphuric and polythionic acids with negative results.

\section{PURIFICATION OF THE OYYGEN AND THE NITROGEN}

The oxygen and nitrogen purification trains are shown in Figure 2. Numbers are placed on parts of the oxygen line and letters on the nitrogen line.

The oxygen line consists of: (1) A cylinder containing oxygen; (2) an electric furnace for heating to $800^{\circ}$ to $900^{\circ} \mathrm{C}$. a tube containing platinized quartz and palladinized asbestos, which catalyzed the oxidation of the hydrogen in the oxygen; (3) a tube containing "dehydrite" $\left(\mathrm{Mg}\left(\mathrm{ClO}_{4}\right)_{2} .3 \mathrm{H}_{2} \mathrm{O}\right)$ and $\mathrm{P}_{2} \mathrm{O}_{5}$ for removing the moisture in the gas; (4) a mercury flow meter.

The nitrogen line consists of: $A$, a cylinder containing nitrogen; $B, C$, a bottle and a spiral each containing an aqueous solution of $\mathrm{NH}_{4} \mathrm{OH}$ and $\mathrm{NH}_{4} \mathrm{Cl}$ in contact with copper filings, for removing the oxygen from the nitrogen; ${ }^{10} D, E, F$, towers containing dilute to concentrated $\mathrm{H}_{2} \mathrm{SO}_{4}$ to remove $\mathrm{NH}_{3} ; G$, a tube containing "ascarite" "(a mixture of hydrated $\mathrm{NaOH}$ and asbestos) for removing any $\mathrm{CO}_{2}$ present, and "dehydrite" for removing moisture; $H, J$, tubes con-

? J. W. Mellor, Modern Inorganic Chemistry, Longmans, Green \& Co., p. 458; 1916.

${ }^{10}$ W. L. Badger, J. Ind. Eng. Chem., 12, p. 161; 1920.

$69882^{\circ}-29-7$ 
taining "dehydrite" and $\mathrm{P}_{2} \mathrm{O}_{5}$, respectively, for removing the last traces of moisture from the nitrogen; $K$, a mercury flow meter.

\section{THE ANALYTICAL METHODS}

The amount of sulphur which was converted to $\mathrm{SO}_{2}$ in any given experiment was determined by weighing the reaction chamber before and after the experiment. The procedure was as follows: The necessary amount of sulphur, 6 to $8 \mathrm{~g}$, was placed in the chamber. Pure dry nitrogen gas was passed through the chamber for about half an hour. Then the chamber was stoppered and weighed. When the experiment was completed, the chamber was again filled with nitrogen in the same manner as before, and weighed. The exterior of the glass chamber was thoroughly cleaned with ether and dried before each weighing. The total weight of the chamber was about $130 \mathrm{~g}$, and the weighings were made to $0.0001 \mathrm{~g}$. The apparent weight of the sulphur which had been used up in the experiment was corrected to vacuum by multiplying by the factor 1.00044 .

As a check on the amount of sulphur burned as determined by direct weighing, the amount of $\mathrm{SO}_{2}$ formed in the experiment was determined by absorbing it in "ascarite." The exit gases from the calorimeter were passed through a cylindrical glass tube, $4 \mathrm{~cm}$ in diameter and $23 \mathrm{~cm}$ tall, containing the "ascarite," together with a layer of "dehydrite" or $\mathrm{P}_{2} \mathrm{O}_{5}$ at the exit end. In order to avoid plugging the absorber and consequent stoppage of the gas flow, the "ascarite" was thoroughly mixed with an equal volume of pumice stone of the same mesh. The absorber was provided with groundglass stoppers. A guard tube containing the same drying agent was attached to the exit end of the absorber during the experiment to prevent back diffusion of moisture from the air.

Initial experiments were made with known amounts of $\mathrm{SO}_{2}$ to determine whether the "ascarite" would absorb it completely. This was found to be the case within the limits of error of the vacuum correction which must be applied to the apparent weight of the $\mathrm{SO}_{2}$ absorbed. The absorber was always filled with pure dry nitrogen and closed at atmospheric pressure before each weighing.

The determination of the vacuum correction to be applied to the apparent weight of $\mathrm{SO}_{2}$ required a knowledge of the change in volume of the "ascarite" which accompanied the absorption of the $\mathrm{SO}_{2}$. For this purpose the assumption was made that the product formed in the absorber was $\mathrm{NaHSO}_{3}$, formed by the reaction of equimolal amounts of $\mathrm{NaOH}$ and $\mathrm{SO}_{2}$. Calculated on this basis, the increase in volume of the solid in the absorber per gram of $\mathrm{SO}_{2}$ absorbed was the difference in the volume of 1 mole of $\mathrm{NaHSO}_{3}$ and 1 mole of $\mathrm{NaOH}$ divided by the molecular weight of $\mathrm{SO}_{2}$. The weight of this volume of nitrogen at the pressure and temperature to which it was subject 


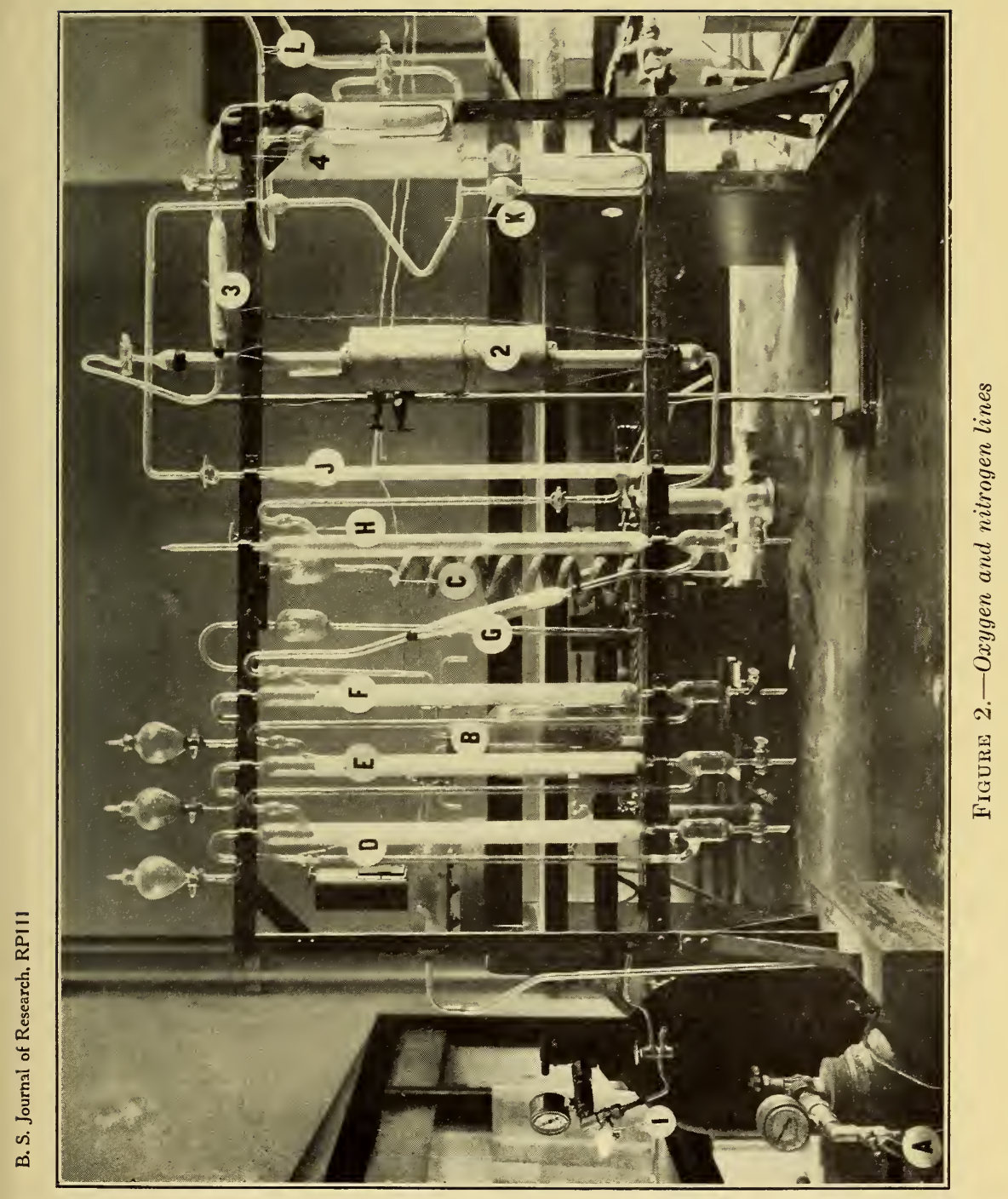

602-1 
B. S. Journal of Research, RPIII

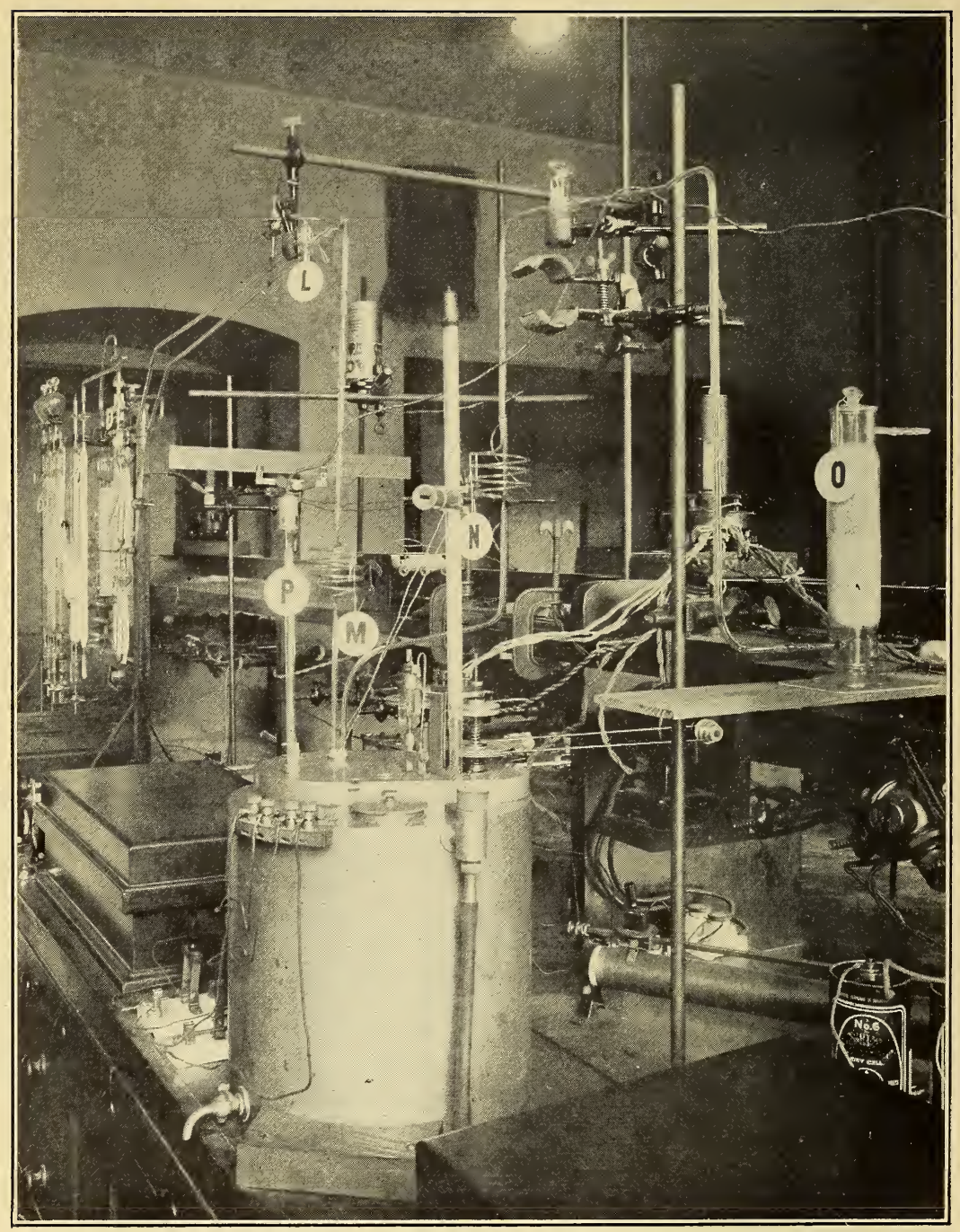

Figure 3.-Calorimeter assembly

$602-2$ 
in the absorber less the weight of the air in the balance case displaced by $1 \mathrm{~g}$ of brass weights is approximately $0.0008 \mathrm{~g}$ per gram of $\mathrm{SO}_{2}$. This correction must be added to the apparent weight of each gram of $\mathrm{SO}_{2}$ absorbed in order to obtain the true mass. This only approximated the true state of affairs, however, because a portion of the "ascarite" in the absorber was changed to $\mathrm{Na}_{2} \mathrm{SO}_{3}$, and because some of the water in the "ascarite" was transferred to subsequent layers of "ascarite" and to the drying agent at the exit end of the tube. All of these possible changes produce a volume change different from that calculated above.

In the first calorimetric experiments three ground glass joints between the calorimeter and the absorber were lubricated with grease, and the $\mathrm{SO}_{2}$ reacted with it to form a product which was caught in the absorber, resulting in too large a weight for the $\mathrm{SO}_{2}$. When this trouble was avoided by using deKhotinsky cement on the joints, and when the absorption of moisture from the room air by the drying agent in the exit end of the absorder was prevented by the use of a suitable guard tube, the number of moles of $\mathrm{SO}_{2}$ absorbed was equal, within the limits of the correction to vacuum and the precision of the weighings of the absorber, to the number of moles of sulphur used up in the reaction as determined by the loss in weight of the sulphur in the reaction chamber. This is shown by the following results:

\begin{tabular}{|c|c|c|c|}
\hline Run & Mole of S & Mole of $\mathrm{SO}_{2}$ & Ratio $\frac{\text { Mole of } \mathrm{SO}_{2}}{\text { Mole of } \mathrm{S}}$ \\
\hline $\begin{array}{l}\mathrm{R} \\
\mathrm{S} \\
\mathrm{S} \\
\mathrm{T}- \\
\mathrm{X}-\end{array}$ & $\begin{array}{r}0.12215 \\
.14101 \\
.13257 \\
.14069\end{array}$ & $\begin{array}{l}0.1222_{3} \\
.1409_{3} \\
.1327_{3} \\
.14074\end{array}$ & $\begin{array}{l}\text { 1. } 001_{1} \\
.999_{4} \\
1.001_{1} \\
1.000_{4}\end{array}$ \\
\hline
\end{tabular}

The $\mathrm{SO}_{2}$ absorber, which had a weight of about $400 \mathrm{~g}$, was weighed to $0.001 \mathrm{~g}$, with a counterpoise of identical dimensions.

In calculating the heat of formation of $\mathrm{SO}_{2}$, the number of moles of $\mathrm{SO}_{2}$ formed was in all of the experiments taken as equal to the number of moles of sulphur which disappeared from the reaction chamber.

\section{THE CALORIMETRIC APPARATUS AND ACCESSORY INSTRUMENTS}

\section{THE CALORIMETER}

The calorimeter (Bureau of Standards inventory No. 13211) used in this work is very similar to the one described by Dickinson. ${ }^{11}$ The calorimeter assembly is shown in Figure 3, and a schematic cross section is shown in Figure 4. The important parts of the

${ }^{11}$ H. C. Dickinson, B. S. Bulletin, 11, p. 189; 1915. B. S. Sci. Paper No. 230; 1914. 
calorimeter assembly are designated in Figure 4 with letters: $A$, water jacket, which was maintained at a constant temperature with the heater $H$ controlled with a toluene-mercury thermostatic regulator and relay in the jacket heater circuit; $B$, jacket stirrer; $C$, calorimeter can filled with water; $D$, platinum resistance thermomoter for determining the temperature of the calorimeter water; $E$, calorimeter stirrer; $F$, Beckmann thermometer, by means of which the jacket temperature was read to $0.001^{\circ} \mathrm{C}$.; $G$, reaction chamber. An air space of about $1 \mathrm{~cm}$ thickness separated the calorimeter can and the jacket.

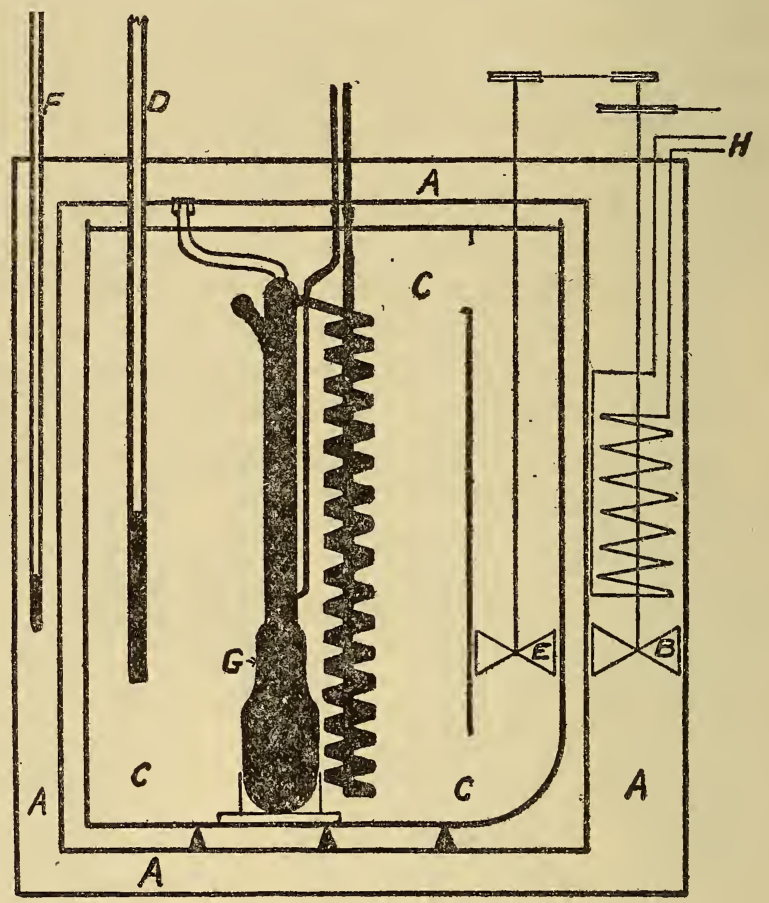

FIGURE 4.-Schematic diagram of the calorimeter

In Figure 3, the letter designations are: $L$, two-way stopcock; $M$, gas inlet into calorimeter; $N$, gas exit from the calorimeter; $O, \mathrm{SO}_{2}$ absorber; $P$, platinum resistance thermometer.

The heat transfer from the jacket to the calorimeter increased the temperature of the latter approximately $0.0021^{\circ}$ per minute per degree difference in temperature.

The energy given to the calorimeter by its stirrer running at 200 r. p. m. was about 4.0 joules per minute.

The temperature of the jacket did not change more than $0.002^{\circ} \mathrm{C}$. in some runs, while in others it changed as much as $0.01^{\circ} \mathrm{C}$. Readings of this temperature were taken every 5 or 10 minutes, so that the jacket temperature change was known to $0.001^{\circ} \mathrm{C}$. Immediately on 
conclusion of a run the platinum thermometer was placed in the jacket, and the Beckmann reading was obtained in terms of the platinum resistance thermometer.

\section{THE THERMOMETER}

The temperature of the calorimeter was determined with a calorimetric type platinum resistance thermometer (Bureau of Standards mark Pt 10). The resistance of the thermometer was read on a Leeds \& Northrup, 8067, Mueller type Wheatstone bridge with a Leeds \& Northrup type $2500 \mathrm{R}$ galvanometer whose scale was $1 \mathrm{~m}$ distant. One millimeter on the galvanometer scale corresponded to 0.0001 ohm (about $0.001^{\circ}$ C.). The bridge was balanced to the nearest $0.0001 \mathrm{ohm}$ and the next figure, corresponding to about $0.0001^{\circ} \mathrm{C}$., was interpolated from the galvanometer deflections. The bridge was calibrated at the beginning of the investigation.

The platinum resistance thermometer had previously been used in the heat division of the bureau, and its calibration data then were: $R_{0}=25.6227 \mathrm{ohms} ; R_{100}-R_{0}=10.0136 \mathrm{ohms} ; \delta=1.487 . \quad R_{0}$ was again measured at the beginning of this work and found to be $25.6230 \mathrm{ohms}$, which value was found unchanged at the end of the investigation.

Eliminating pt from the Callendar formula,

$$
\begin{aligned}
t & =\mathrm{pt}+\delta\left(\frac{t}{100}-1\right) \frac{t}{100} \\
\mathrm{pt} & =\left(\frac{R-R_{0}}{R_{100}-R_{0}}\right) 100
\end{aligned}
$$

and rearranging, one obtains:

$$
R=R_{0}+\frac{R_{100}-R_{0}}{100}\left(1+\frac{\delta}{100}\right) t-\delta \frac{\left(R_{100}-R_{0}\right)}{10^{6}} t^{2}
$$

Substituting the values of $R_{0}, R_{100}-R_{0}$, and $\delta$, there results the equation giving the resistance $R$, in terms of $t$, the temperature in ${ }^{\circ} \mathrm{C}$.:

$$
R=25.6230+0.101625 t-0.00001489 t^{2}
$$

Differentiating, one finds

$$
\begin{aligned}
\frac{\mathrm{d} R}{\mathrm{~d} t} & =0.101625-0.00002978 t \\
\frac{\mathrm{d}^{2} R}{\mathrm{~d} t^{2}} & =-0.00002978
\end{aligned}
$$

For $25.00^{\circ}$ C., $\frac{\mathrm{d} R}{\mathrm{~d} t}=0.100880^{\circ} \mathrm{ohm}$ per degree, and the change in $\frac{\mathrm{d} R}{\mathrm{~d} t}$ is -0.000030 ohm per degree per degree. In translating a resistance change of several tenths of an ohm into the corresponding 
temperature rise in ${ }^{\circ} \mathrm{C}$, , the resistance change is divided by the proper value of $\frac{\mathrm{d} R}{\mathrm{~d} t}$ for the given average temperature of the rise. ${ }^{12}$

\section{THE ELECTRICAL ENERGY SYSTEM}

The supply of electrical energy came from a battery of lead storage cells of 30 volts, maintained in the electrical division of the bureau. The current was determined by measuring the potential drop across a standard $0.1 \mathrm{ohm}$ resistance on a Leeds No. 3316 potentiometer. The voltage drop was taken from points on the current leads exactly midway between the calorimeter and the jacket. The leads were in good thermal contact with, but electrically insulated from, the jacket case. A Leeds \& Northrup type 2500 galvanometer with scale $1 \mathrm{~m}$. distant was used in conjunction with the potentiometer, whose smallest decade consisted of nine 0.00001 volt steps.

The potentiometer was calibrated, and the resistance of the standard $0.1 \mathrm{ohm}$ measured by the electrical division of the bureau. An

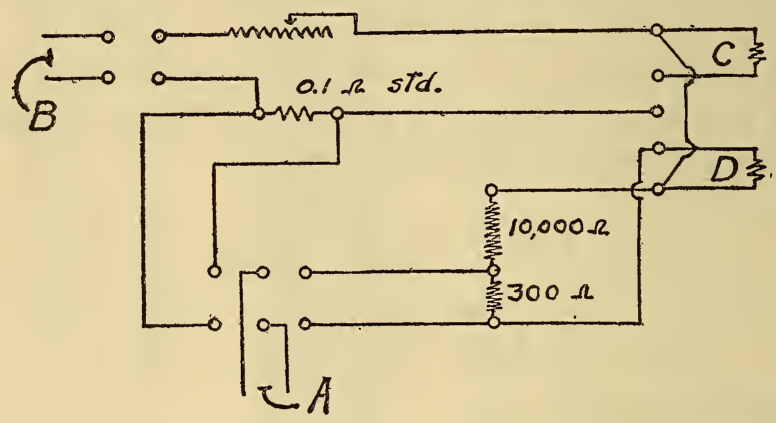

Figure 5.-Diagram of the electrical energy system

$A$, to potentiometer; $B$, to storage battery; $C$, substitute resistance; $D$, heating coil in reaction chamber.

Eppley, No. 34701, standard cell, checked against the standards of the bureau, was used with the potentiometer. The stop watch (Bureau of Standards inventory No.37091E), used to measure the time of the energy input, was calibrated for intervals of 60,300 , and 3,600 seconds by the weights and measures division of the bureau.

A diagram of the electrical circuit is shown in Figure 5. Since a very small part of the current which was measured on the $0.1 \mathrm{ohm}$ standard resistance passed through the $10,300 \mathrm{ohms}$ which are in parallel with the heating coil, a factor of $1-\frac{r}{10,300}$ was applied to the measured electrical energy, $r$ being the resistance of the heating coil. The potentiometer measured $\frac{300}{10,300}$ of the potential drop across the heating coil. Each of the coils in the two resistance boxes which determined this latter ratio were calibrated in the electrical division of the bureau.

12 For a complete discussion of this method see H. C. Dickinson and E. F. Mueller, B. S. Bulletin, 9, p. 483; 1913; B. S. Sci. Paper No. 200; 1913. 
The actual potentiometer readings for both the current and voltage were about 0.25000 volt and were read and recorded to five significant figures. All the electrical instruments had been calibrated to 0.01 per cent.

It should be pointed out here that the above method of measuring the electrical energy really determines $\frac{E^{2}}{R}$, and not $E \times I$. With a given current flow, readings of the potential drop across the $0.1 \mathrm{ohm}$ standard resistance and across the heating coil give directly the ratio of the two resistances. For convenience in discussion and calculation, however, the current $I$ will be used in place of $\frac{E}{P}$ throughout this paper.

When electrical energy was supplied to the reaction chamber at a rate of 20 joules per second, the temperature of the heating coil rose to the neighborhood of $400^{\circ} \mathrm{C}$., because the vacuum jacket prevented the rapid transfer of energy from the coil to the water in the calorimeter. Because of the rapid increase in the resistance of the platinum coil with the temperature, the current decreased and the voltage drop increased from the initial value until a steady state was reached. The initial value of the current and voltage could be calculated from a knowledge of the initial resistance of the platinum wire, the total resistance in the line, and the voltage of the battery of cells which supplied the energy. The steady state current and voltage were reached in about three minutes, with the greater part of the change occurring in the first minute.

In every run two readings of the voltage and two of the current were made in the first minute, then a reading every half minute. These readings, along with the calculated initial current and voltage, when plotted, gave curves similar to that in Figure 6. The energy during the first period of the rapidly changing resistance was found by calculating, from the curves, the product of the average voltage and average current for each 12 -second interval for the first minute, and then for each 30-second interval until the last half minute of the 4-minute period, when two 15 -second intervals were taken. In the $\mathrm{SO}_{2}$ experiments, the oxygen was turned on $3 \frac{1}{2}$ minutes after the current was switched on, and the added increase in temperature and resistance of the coil due to the reaction energy was evidenced by a sudden small jump in the voltage and a drop in the current. This is shown in Figure 6. The electrical energy supply for the sulphur runs was cut off at the end of the fourth minute.

The energy curves for the calibration runs were similar to those for the $\mathrm{SO}_{2}$ experiments except that the current and voltage were practically constant after the third minute until the electrical energy was cut off at the end of the heating time of 50 to 60 minutes. 


\section{MOLECULAR WEIGHTS, CONSTANTS, FACTORS, UNITS, ETC.}

The atomic weight of sulphur was taken as 32.065 and the molecular weight of $\mathrm{SO}_{2}$ as 64.065 .

All weighings, both of sulphur and of water, were corrected to vacuum, with the factors 1.00044 and 1.00106, respectively. In calculating these factors, the following densities, in $\mathrm{g} / \mathrm{cm}^{3}$, were used: Brass weights, 8.4; dry nitrogen in the reaction chamber, 0.00117; water, 0.998; air in the balance case, 0.0012; rhombic sulphur, 2.07.

The electrical energy was measured in international joules, since the instruments had been calibrated in terms of the international

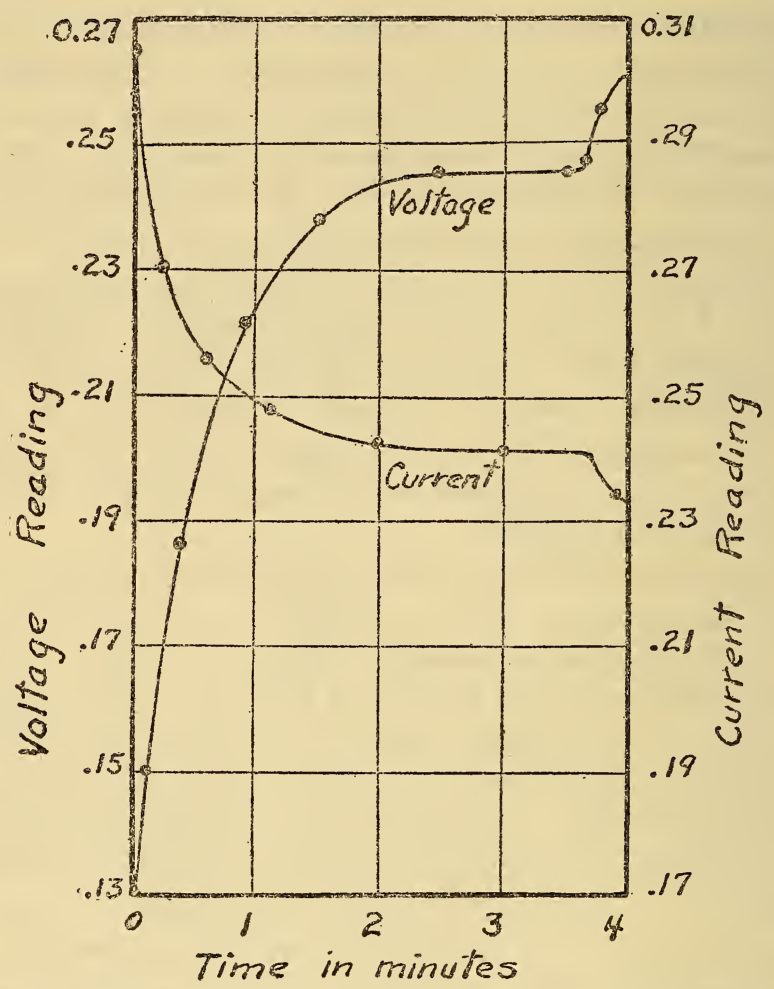

Frgure 6.-Time variation of the current and voltage in a sulphur experiment

ohm and the international volt. In converting the final value for the heat of formation of $\mathrm{SO}_{2}$ from international to absolute joules, 1. international joule was taken to equal $1.00034^{13}$ absolute joules.

For the purpose of comparing the heat capacities of the slightly different amounts of water which were used in the various experiments, and the slightly different mean temperatures of the experi- 
ments, the heat capacity of water at $25^{\circ} \mathrm{C}$. was taken as 4.178 joules per gram per degree and its temperature coefficient ${ }^{14}$ at $25^{\circ} \mathrm{C}$. as -0.0005 joule per gram per degree per degree.

\section{THE CALORIMETRIC PROCEDURE}

\section{CALIBRATION EXPERIMENTS}

The calorimetric procedure consisted in determining the amount of electrical energy which would bring about a temperature rise in the calorimeter equivalent to that produced by the formation of a given amount of $\mathrm{SO}_{2}$ in the same calorimeter and apparatus at the same average temperature under the same operating conditions.

The constant-temperature-jacket method was followed in conducting the experiments. The initial temperatures of the calorimeter and of the jacket were so adjusted that, at the end of a run, the temperature of the calorimeter would be equal to, or slightly below,

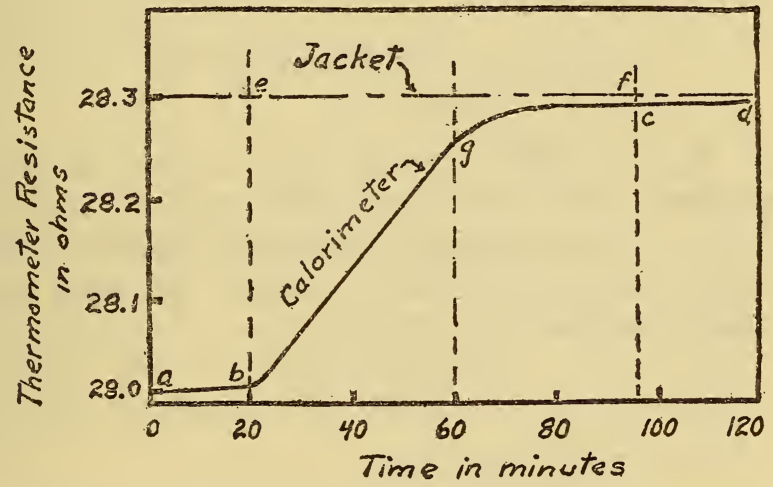

Figure 7.-Time-temperature curve of the calorimeter in a sulphur experiment

that of the jacket, and the average of the initial and final temperatures of the calorimeter would be $25^{\circ} \mathrm{C}$.

A typical time-temperature curve for the calorimeter during a sulphur run is given in Figure 7. The shape of the corresponding curve in the calibration runs was the same except that the time from $g$ to $c$, in which temperature uniformity was attained, was 20 instead of 35 minutes as in the sulphur runs. Observations of the calorimeter temperature were made during the period from $a$ to $b$. At $b$, energy was supplied to the calorimeter and its temperature rose steadily, and almost linearly, to $g$, when the energy supply, either reaction or electrical, was cut off. Temperature uniformity was attained at $c$, and temperature readings were continued to $d$.

The corrections applied to $R_{c}-R_{b}$, which will be designated as $\Delta R$, the main temperature rise, were two: First, a correction which is

14 Int. Crit. Tables, 5, p. 78. 
independent of the temperature difference between the calorimeter and the jacket, and is constant with time; and, secondly, a correction which is directly proportional to the temperature difference between the calorimeter and the jacket. The first correction includes the energy given to the calorimeter through stirring and probably a large part of the energy removed from it through evaporation; and the second correction consists, in a large measure, of the flow of energy from the jacket to the calorimeter. In the following discussion, $u$ is the first correction in "ohms" per minute; $k$ is the proportionality factor, in "ohms" per minute per "ohm," for the second correction; $R$ is the calorimeter temperature and $R_{j}$ the jacket temperature, both in "ohms," at the time $Z$, in minutes.

The following equations hold to a high degree of approximation:

$$
\begin{aligned}
& u+\left(R_{j(a, b)}-\frac{R_{a}+R_{b}}{2}\right) k=\frac{R_{b}-R_{a}}{Z_{b}-Z_{a}} \\
& u+\left(R_{j(c, d)}-\frac{R_{c}+R_{d}}{2}\right) k=\frac{R_{d}-R_{c}}{Z_{d}-Z_{c}}
\end{aligned}
$$

$R_{j(a, b)}$ and $R_{j(c, d)}$ are the averages with respect to time, of the jacket temperatures over the periods $a$ to $b$ and $c$ to $d$, respectively. $Z_{b}-Z_{a}$ and $Z_{a}-Z_{c}$ were usually 20 and 25 minutes, respectively. These two equations were solved for $u$ and $k$ for each experiment. The total value of the first correction is:

$$
\bar{U}=u\left(Z_{c}-Z_{b}\right)
$$

and that of the second correction is:

$$
K=k(\text { area } b, g, c, f, e)
$$

$Z_{c}-Z_{b}$ was usually 75 or 80 minutes.

The corrected temperature rise in "ohms" is then given by the following equation:

$$
\Delta R_{\text {corr. }}=\left(R_{c}-R_{b}\right)-K-U
$$

The above mothod will give the corrected temperature rise to a high degree of precision provided that both $k$ and $u$ are constant over the period of a single experiment; that is, from $Z_{a}$ to $Z_{d}$. The effect of evaporation was minimized by having the calorimeter temperature always below that of the jacket. If the stirring speed is constant, the stirring energy will be constant except for a very small decrease, due to the decrease in viscosity of the water with rise in temperature.

Since, for the procedure adopted in these experiments, the coefficient of $k$ in equation (5) was small compared with that in equation (6), the above method of calculation amounts to determining $k$ at the beginning and $u$ at the end of the experiment. Any small absolute 
error in this method of determining the true temperature rise will not affect the final result of the investigation, since the same procedure was followed in both the calibration and sulphur combustion runs:

For a calibration run, the electrical energy input for the first three or four minutes was calculated as explained in Part IV, section 3, and the electrical energy over the remainder of the run was found by taking the product of the average current and voltage. Since dry nitrogen gas at a rate of 70 to $100 \mathrm{ml}$ per minute was passed through the chamber in order to increase the rate of transfer of energy from the heating coil in the reaction chamber to the water surrounding it, proper corrections when necessary were applied to $R_{b}-R_{a}, R_{d}-R_{c}$, and $R_{c}-R_{b}$, for the amount of energy given to or removed from the calorimeter by the nitrogen gas. All the appropriate corrections and calibration data were applied to the readings of the potentiometer, the Mueller bridge, the stop watch, the room thermometer, etc.

The following equation was used to calculate the heat capacity of the calorimeter (can, reaction chamber, thermometer) plus the water:

$$
C_{p\left(\text { calor. }+\mathrm{H}_{2} \mathrm{O}\right)}=\frac{\text { elec. energy }+ \text { " } \mathrm{N}_{2} \text { energy" }}{\Delta t_{\text {corr. }}}
$$

The results of seven calibration experiments are given in Table 1. Experiments 1 to 7, inclusive, could not be calculated because of failure to secure a sufficient number of readings in the period of rapidly changing current and voltage or because of difficulties with the jacket heater and thermostatic control. The result of run 10 is obviously not in accord with the others and is omitted in taking the average.

TABLe 1.-Calibration experiments

\begin{tabular}{|c|c|c|c|c|c|c|c|c|c|c|c|}
\hline Run & $\Delta R$ & $k$ & \multicolumn{2}{|c|}{$u$} & \multicolumn{2}{|c|}{$K$} & \multicolumn{2}{|c|}{$U$} & $\Delta R_{\text {corr }}$ & $\frac{\mathrm{d} R}{\mathrm{~d} t}$ & $\Delta t_{\text {corr }}$ \\
\hline $\begin{array}{r}8 \\
9 \\
10 \\
11 \\
12 \\
13 \\
14 \\
\end{array}$ & $\begin{array}{l}\text { Ohms } \\
0.63733 \\
.39264 \\
.40329 \\
.40000 \\
.30614 \\
.40627 \\
.40486\end{array}$ & $\begin{array}{r}\text { Ohms/min./ } \\
\text { ohm } \\
0.001994 \\
.002002 \\
.002034 \\
.001996 \\
.001986 \\
.001995 \\
.002017\end{array}$ & \multicolumn{2}{|c|}{$\begin{array}{r}\text { Ohms/min. } \\
0.0000566 \\
.0000277 \\
.0000346 \\
.0000357 \\
.0000648 \\
.0000223 \\
.0000205\end{array}$} & \multicolumn{2}{|c|}{$\begin{array}{l}\text { Ohms } \\
0.05549 \\
.02172 \\
.03040 \\
.02719 \\
.01722 \\
.02996 \\
.02979\end{array}$} & \multicolumn{2}{|c|}{$\begin{array}{l}\text { Ohms } \\
0.00509 \\
.00221 \\
.00277 \\
.00286 \\
.00421 \\
.00178 \\
.00164\end{array}$} & $\begin{array}{l}\text { Ohms } \\
0.57675 \\
.35871 \\
.37012 \\
.3695 \\
.28471 \\
.37453 \\
.37343\end{array}$ & $\begin{array}{c}\text { Ohms per } \\
\circ \text { C. } \\
0.100886 \\
.100873 \\
.100882 \\
.100870 \\
.100881 \\
.100883 \\
.100877\end{array}$ & $\begin{array}{l}\circ C \text {. } \\
5.7168 \\
3.6552 \\
3.6688 \\
3.6676 \\
2.8222 \\
3.7125 \\
3.7018\end{array}$ \\
\hline \multicolumn{2}{|c|}{ Run } & \multicolumn{2}{|c|}{$\begin{array}{l}\text { A verage } \\
\text { temp. }\end{array}$} & \multicolumn{2}{|c|}{$\begin{array}{c}\text { Electrical } \\
\text { energy }\end{array}$} & \multicolumn{2}{|c|}{$\begin{array}{l}\text { "N2 } \mathrm{N}_{2} \\
\text { energy" }\end{array}$} & \multicolumn{2}{|c|}{$\underset{\mathrm{H}_{2} \mathrm{O}}{\text { Mass of }}$} & $\begin{array}{c}C_{p(\text { calor }} \\
\left.+\mathrm{H}_{2} \mathrm{O}\right)\end{array}$ & $\begin{array}{l}\text { Deviation } \\
\text { from the } \\
\text { mean }\end{array}$ \\
\hline $\begin{array}{r}8 . \\
9 \\
10 . \\
11 . \\
12 . \\
13 \\
14 .\end{array}$ & & \multicolumn{2}{|c|}{$\begin{array}{l}\circ C . \\
24.80 \\
25.27 \\
24.94 \\
25.37 \\
25.02 \\
24.91 \\
25.14\end{array}$} & \multicolumn{2}{|c|}{$\begin{array}{r}\text { Int. joules } \\
87,659 \\
55,112 \\
55,824 \\
55,596 \\
43,203 \\
56,966 \\
56,698\end{array}$} & \multicolumn{2}{|c|}{$\begin{array}{l}\text { Joules } \\
+11 \\
-17 \\
-8 \\
-7 \\
-2 \\
-1 \\
-9\end{array}$} & & $\begin{array}{c}g \\
3,592.2 \\
3,531.6 \\
3,556.6 \\
3,551.8 \\
3,584.4 \\
3,594.6 \\
3,586.3 \\
\text { lean.-.-- }\end{array}$ & $\begin{array}{c}\text { Int. joules } 1 \\
15,368 \\
15,360 \\
(15,395) \\
15,359 \\
15,373 \\
15,366 \\
15,371 \\
15,366.2\end{array}$ & $\begin{array}{r}\text { Joules } \\
+1.8 \\
-6.2 \\
-7.2 \\
+6.8 \\
-0.2 \\
+4.8 \\
\pm 4.5\end{array}$ \\
\hline
\end{tabular}

1 Corrected to $3,600 \mathrm{~g} \mathrm{H}_{2} \mathrm{O}$ and $25^{\circ} \mathrm{O}$. 
The arithmetical mean of the six experiments for the heat capacity of the calorimeter plus $3,600 \mathrm{~g} \mathrm{H}_{2} \mathrm{O}$ at $25^{\circ} \mathrm{C}$. is $15,366.2$ joules per degree, with an average deviation from the mean of 0.029 per cent, a "probable error" of the mean of 0.010 per cent, and a maximum deviation from the mean of 0.047 per cent. A calculation of the heat capacity of the calorimeter from the masses and heat capacities of its parts, including the partly immersed platinum thermometer, assuming the heat capacity of water to be 4.178 joules per gram per degree at $25^{\circ} \mathrm{C}$., gave a result of 15,373 joules.

\section{SULPHUR DIOXIDE EXPERIMENTS}

The $\mathrm{SO}_{2}$ experiments were made under exactly the same conditions as the calibration experiments, and the time-temperature curves were similar except that a longer time was required to reach temperature uniformity at the end of the run because of the presence of sulphur in the chamber.

Two special runs, $\alpha$ and $\beta$, were made to determine approximately how much of the remaining sulphur failed to return to the rhombic form in the time $Z_{g}$ to $Z_{c}$. In these two runs no sulphur was burned, but electrical energy supplied to the calorimeter at the usual rate for 4 minutes in run $\alpha$ and 10 minutes in run $\beta$. Since the heat content of monoclinic sulphur is greater than that of rhombic sulphur, the following equation should hold:

$$
\text { electrical energy }=\Delta t_{\text {corr. }} C_{p\left(\text { calor. }+\mathrm{H}_{2} \mathrm{O}+\mathrm{S}\right)}+q
$$

where $q$ is the energy which has been retained by that portion of sulphur which has not returned to the rhombic form. The results of the two runs are:

\begin{tabular}{|c|c|c|}
\hline Run & $\begin{array}{c}\text { g sulphur } \\
\text { in chamber }\end{array}$ & $q$ \\
\hline & & $\begin{array}{c}\text { Joules } \\
15 \\
\alpha\end{array}$ \\
$\beta$ & 10 & 14 \\
\hline
\end{tabular}

This is about 1.5 joules per gram of suphur remaining in the chamber. Since the heat absorbed when $1 \mathrm{~g}$ of rhombic sulphur changes to the monoclinic form is about 9 joules, this calculation indicates that only a small part (one-sixth, if the data be treated as exact) of the sulphur remained in the monoclinic form in these experiments. Presumably this remaining small amount of monoclinic sulphur was changing very slowly, so that its effect on the value of $R_{d}-R_{c}$ is negligible.

A sample data sheet giving the readings for an $\mathrm{SO}_{2}$ experiment is given in Table 2. Appropriate corrections were applied to the readings as in the case of the calibration experiments. The heat capacity of the calorimeter plus $3,600 \mathrm{~g} \mathrm{H}_{2} \mathrm{O}$ was taken as 15,367 
joules per degree $(15,366.2+0.8$, because a small amount of ground pyrex glass, having a heat capacity of 0.8 joule per degree was later placed in the cooling coil of the reaction chamber) plus the heat capacity of the sulphur remaining in the chamber plus the heat capacity of one-half of the sulphur used up in the experiment. This last addition to the heat capacity of the system was necessary because the temperature of the experiment was taken as the average of the initial and final temperatures.

The heat of formation of 1 mole of $\mathrm{SO}_{2}$ at the average temperature of the experiment was calculated by the following formula:

$$
Q_{t}=\frac{\Delta t_{c o r r}, \mathrm{C}_{p\left(\text { calor },+\mathrm{H}_{2} \mathrm{O}+\mathrm{S}\right)}-\left[\text { elec. energy }+ \text { " } \mathrm{O}_{2}, \mathrm{~N}_{2}\right. \text {, energy" }}{+ \text { "Tr. energy"] }}
$$

in which $m$ is the number of moles of sulphur converted to $\mathrm{SO}_{2}$; " $\mathrm{O}_{2}, \mathrm{~N}_{2}$, energy" is the energy given to the calorimeter by the oxygen and nitrogen gases; "Tr. energy" is the energy involved in the transformation of rhombic to monoclinic sulphur, and was taken as -1.5 joules per gram of sulphur remaining in the chamber. The " $\mathrm{O}_{2}, \mathrm{~N}_{2}$ energy" correction was calculated by determining the average (with respect to time) temperature of the incoming gases and of the calorimeter water. The difference of these two temperatures multiplied by the heat capacity of all the incoming gases gives the value of the correction. If the mean-time temperature of the calorimeter was below that of the incoming gases, energy was given to the calorimeter by the gases. At any given time the $\mathrm{SO}_{2}$ gas left the calorimeter at the temperature of the calorimeter water.

TABLE 2.-Sulphur dioxide experiment No. X

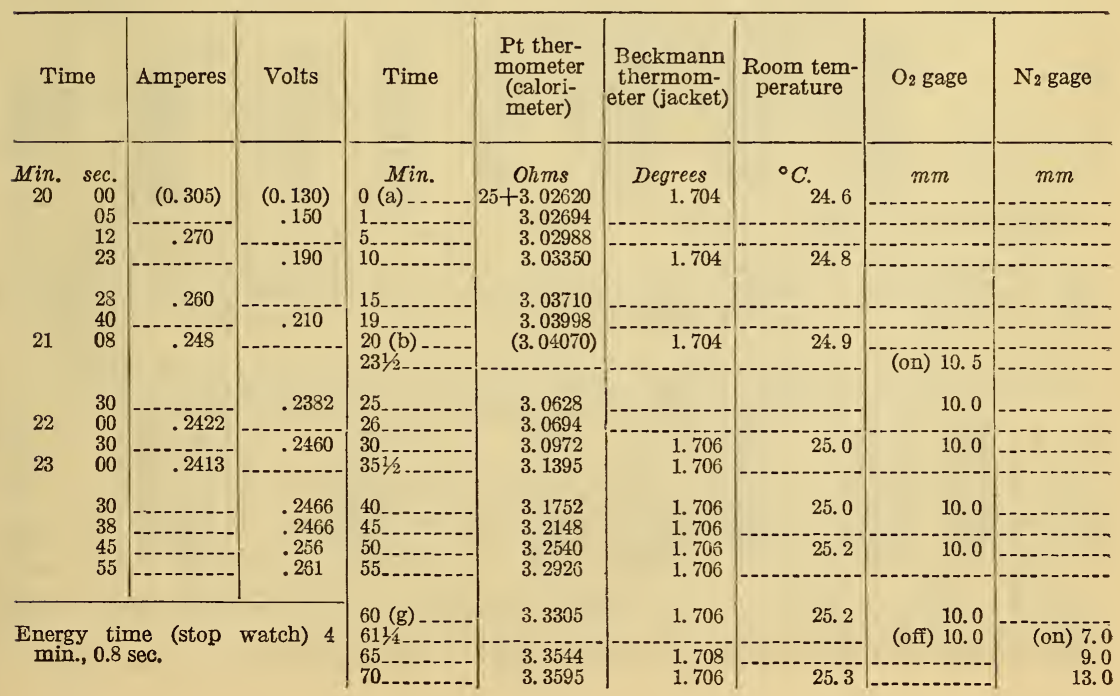


TABLe 2.-Sulphur dioxide experiment No. X-Continued

Volt ratio: $\frac{10300}{300}$

Mass sulphur: $4.5112 \mathrm{~g}$

Mass water: $3,603.0 \mathrm{~g}$

Mass $\mathrm{SO}_{2}: 9.016 \mathrm{~g}$

\begin{tabular}{|c|c|c|c|c|c|}
\hline Time & $\begin{array}{l}\text { Pt ther- } \\
\text { mometer } \\
\text { (calori- } \\
\text { meter) }\end{array}$ & $\begin{array}{c}\text { Beckmann } \\
\text { thermom- } \\
\text { eter (jacket) }\end{array}$ & $\begin{array}{l}\text { Room tem- } \\
\text { perature }\end{array}$ & $\mathrm{O}_{2}$ gage & $\mathrm{N}_{2}$ gage \\
\hline Min. & $\begin{array}{l}\text { Ohms } \\
\text { 3. } 36145\end{array}$ & $\begin{array}{l}\text { Degrees } \\
\quad 1.706\end{array}$ & ${ }^{\circ} \mathrm{C}$. & $m m$ & $m m$ \\
\hline $\begin{array}{l}80 \ldots \\
85\end{array}$ & $\begin{array}{l}\text { 3. } 36227 \\
\text { 3. } 36266\end{array}$ & $\begin{array}{l}\text { 1. } 706 \\
\text { 1. } 707\end{array}$ & 25.3 & & 13.0 \\
\hline 90 & 3. 36287 & 1. 707 & 25.2 & - & (off) 13.0 \\
\hline $\begin{array}{l}95(\mathrm{c}) \\
100\end{array}$ & $\begin{array}{l}\text { 3. } 36304 \\
\text { 3. } 36318\end{array}$ & $\begin{array}{l}\text { 1. } 708 \\
1.708\end{array}$ & 25.2 & & - \\
\hline 105 & 3. 36332 & 1. 709 & & & \\
\hline & 3. 36347 & $\begin{array}{l}1.710 \\
1.708\end{array}$ & 25.2 & & \\
\hline $120(\mathrm{~d})$ & 3. 36374 & 1. 708 & 25.1 & -1 & \\
\hline 125 & 3. 3694 & $\sim \quad 1.708$ & $\begin{array}{l}\text { Correction: } \\
-0.4^{\circ} \mathrm{C} \text {. }\end{array}$ & $\begin{array}{l}10.0 \mathrm{~mm} \sim \\
0.10 \mathrm{~L} \\
\text { per min. }\end{array}$ & $\begin{array}{l}13.0 \mathrm{~mm} \sim \\
0.13 \mathrm{~L} \\
\text { per min. }\end{array}$ \\
\hline
\end{tabular}

\section{For the reaction}

$$
\mathrm{S}_{\mathrm{rh} \cdot(\text { solid) }}+\mathrm{O}_{2 \text { (gas) }}=\mathrm{SO}_{2 \text { (gas) }} \cdot\left(25^{\circ} \text { C. }\right)
$$

the increase in heat capacity, $\Delta \mathrm{c}_{p}$, is -12 joules per degree per mole. This very small correction was applied in calculating the values of $Q_{25}$ from those experiments which were made at average temperatures slightly different from $25^{\circ} \mathrm{C}$. In obtaining this value of $\Delta_{\mathrm{C}_{p}}$, the following heat capacities, in joules per mole per degree, were used: $\mathrm{S}, 23 ; \mathrm{O}_{2}, 29.4$; and $\mathrm{SO}_{2}, 40.6$.

TABLE 3.-Sulphur dioxide experiments (first series)

\begin{tabular}{|c|c|c|c|c|c|c|c|c|c|c|}
\hline \multicolumn{2}{|c|}{ Run } & $\Delta R$ & $\dot{k}$ & \multicolumn{2}{|l|}{$u$} & $K$ & $U$ & $\Delta R$ corr. & $\frac{d R}{d t}$ & $\Delta t_{\text {corr. }}$ \\
\hline \multicolumn{2}{|c|}{$\begin{array}{l}\mathrm{A} \\
\mathrm{B} \\
\mathrm{B} \\
\mathrm{C} \\
\mathrm{D} \\
\mathrm{D} \\
\mathrm{E} \\
\mathrm{G} \\
\mathrm{G} \\
\mathrm{H} \\
\mathrm{H}\end{array}$} & $\begin{array}{l}\text { Ohms } \\
0.38213 \\
.39599 \\
.38263 \\
.24225 \\
.30065 \\
.27847 \\
.27863\end{array}$ & $\begin{array}{c}\text { Ohms/min./ } \\
\text { ohm } \\
0.001960 \\
.001971 \\
.001980 \\
.001936 \\
.001939 \\
.002022 \\
.001981\end{array}$ & \multicolumn{2}{|c|}{$\begin{array}{r}\text { Ohms/min. } \\
0.0000670 \\
.0000071 \\
.0000069 \\
.0000142 \\
-.0000025 \\
.0000035 \\
.0000086\end{array}$} & $\begin{array}{c}\text { Ohms } \\
0.02288 \\
.02405 \\
.02194 \\
.01051 \\
.01165 \\
.01226 \\
.01270\end{array}$ & $\begin{array}{c}\text { Ohms } \\
0.00603 \\
.00064 \\
.00062 \\
.00107 \\
-.00018 \\
.00018 \\
.00060\end{array}$ & \begin{tabular}{c|} 
Ohms \\
0.35322 \\
.37130 \\
.36007 \\
.23067 \\
.28918 \\
.26603 \\
.26533
\end{tabular} & $\begin{array}{r}\mathrm{Ohms} /{ }^{\circ} \mathrm{C} . \\
0.100878 \\
.100892 \\
.100892 \\
.100880 \\
.100881 \\
.100880 \\
.100864\end{array}$ & $\begin{array}{l}{ }^{\circ} C . \\
3.5016 \\
3.6802 \\
3.5689 \\
2.2866 \\
2.8665 \\
2.6371 \\
2.6305\end{array}$ \\
\hline Run & $\begin{array}{c}\text { Average } \\
\text { temper- } \\
\text { ature }\end{array}$ & $\begin{array}{c}\text { Mass of } \\
\mathrm{H}_{2} \mathrm{O}\end{array}$ & $\begin{array}{c}\mathrm{C}_{\mathrm{p}} \\
\text { (calor.+ } \\
\mathrm{H}_{2} \mathrm{O}+\mathrm{S} \text { ) }\end{array}$ & $\begin{array}{l}\text { Elec- } \\
\text { trical } \\
\text { energy }\end{array}$ & $\begin{array}{l}\text { " } \mathrm{O}_{2}, \mathrm{~N}_{2} \\
\text { energy" }\end{array}$ & " energy" & $\underset{\mathrm{S}}{\text { Moles of }}$ & $\begin{array}{c}\text { Correc- } \\
\text { tion to } \\
25.00^{\circ} \mathrm{C}^{1}\end{array}$ & $Q, 25^{\circ} \mathrm{C}$ & $\begin{array}{l}\text { Devia- } \\
\text { tion } \\
\text { from the } \\
\text { mean. }\end{array}$ \\
\hline \multirow[t]{2}{*}{$\begin{array}{l}\mathrm{A} \\
\mathrm{B} \\
\mathrm{C} \\
\mathrm{D} \\
\mathrm{D}\end{array}$} & \multirow[t]{2}{*}{$\begin{array}{l}{ }^{\circ} C . \\
25.24 \\
24.58 \\
24.59 \\
24.99 \\
24.97 \\
25.01 \\
25.52\end{array}$} & \multirow[t]{2}{*}{$\begin{array}{c}g \\
3,602.6 \\
3,588.1 \\
3,581.8 \\
3,593.7 \\
3,603.5 \\
3,613.8 \\
3,604.9\end{array}$} & \multirow[t]{2}{*}{$\begin{array}{r}\text { Int. } \\
\text { joules/ } \\
15,383 \\
15,324 \\
15,298 \\
15,347 \\
15,388 \\
15,431 \\
15,393\end{array}$} & \multirow[t]{2}{*}{$\begin{array}{c}\text { Int. } \\
\text { joules } \\
5,341 \\
4,687 \\
4,690 \\
4,739 \\
4,546 \\
4,990 \\
5,100\end{array}$} & \multirow[t]{2}{*}{$\begin{array}{r}\text { Joules } \\
-24 \\
-22 \\
-14 \\
-19 \\
-30 \\
-19 \\
-21\end{array}$} & \multirow[t]{2}{*}{$\begin{array}{r}\text { Joules } \\
-6 \\
-5 \\
-6 \\
-10 \\
-8 \\
-10 \\
-10\end{array}$} & \multirow[t]{2}{*}{$\begin{array}{r}0.16370 \\
.17441 \\
.16826 \\
(.10265) \\
.13331 \\
.12033 \\
.11950\end{array}$} & $\begin{array}{r}\text { Joules/ } \\
\text { mole } \\
-3 \\
5 \\
5 \\
0 \\
0 \\
0 \\
-6\end{array}$ & \begin{tabular}{|c} 
Int.joules| \\
mole \\
$+296,600$ \\
296,630 \\
296,730 \\
$(296,000)$ \\
297,050 \\
296,950 \\
296,420
\end{tabular} & $\begin{array}{r}\text { Joules } \\
-130 \\
-100 \\
0 \\
+320 \\
+220 \\
-310\end{array}$ \\
\hline & & & & & & & & Mean.. & $-296,730$ & \pm 180 \\
\hline
\end{tabular}

1 This correction $=\left(\Delta C_{p}\right) \times$ (average temperature $\left.-25.00^{\circ} \mathrm{C}.\right) . \quad \Delta C_{p}=-12$ joules per mole per degree. 
TABLE 4.-Sulphur dioxide experiments (second series)

\begin{tabular}{|c|c|c|c|c|c|c|c|c|c|c|}
\hline \multicolumn{2}{|c|}{ Run } & $\Delta R$ & $k$ & \multicolumn{2}{|l|}{$u$} & $K$ & \multicolumn{2}{|r|}{$\Delta R_{\text {eorr. }}$} & $\frac{d R}{d t}$ & $\Delta t_{\text {corr. }}$ \\
\hline 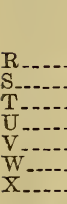 & & $\begin{array}{l}\text { Ohms } \\
0.23106 \\
.32202 \\
.30350 \\
.31046 \\
.33854 \\
.32501 \\
.32260\end{array}$ & $\begin{array}{l}\text { Ohms/min, } \\
\text { ohm } \\
0.002053 \\
.002023 \\
.001978 \\
.001987 \\
.002108 \\
.002091 \\
.002119\end{array}$ & \multicolumn{2}{|c|}{$\begin{array}{r}\text { Ohms/min. } \\
0.0000128 \\
-.0000019 \\
.0000139 \\
.0000242 \\
.0000038 \\
.0000182 \\
.0000151\end{array}$} & $\begin{array}{l}\text { Ohms } \\
.01227 \\
.01617 \\
.01392 \\
.01465 \\
.01802 \\
.01796 \\
.01707\end{array}$ & $\begin{array}{c}\text { oh ms } \\
0.00096 \\
-.00014 \\
.00104 \\
.00181 \\
.00029 \\
.00136 \\
.00113\end{array}$ & $\begin{array}{l}\text { Ohms } \\
0.26783 \\
.30599 \\
.28854 \\
.29400 \\
.32023 \\
.30569 \\
.30440\end{array}$ & $\begin{array}{r}\mathrm{Ohms} /{ }^{\circ} \mathrm{C} . \\
0.100865 \\
.100871 \\
.100870 \\
.100868 \\
.100865 \\
.100865 \\
.100866\end{array}$ & $\begin{array}{l}{ }^{\circ} \mathrm{C} . \\
2.6553 \\
3.0334 \\
2.8605 \\
2.9146 \\
3.1748 \\
3.0307 \\
3.0179\end{array}$ \\
\hline Run & $\begin{array}{l}\text { Average } \\
\text { temper- } \\
\text { ature }\end{array}$ & $\underset{\mathrm{H}_{2} \mathrm{O}}{\text { Mass of }}$ & $\begin{array}{c}\mathrm{Cp}_{p} \\
\text { (calor. }+ \\
\left.\mathrm{H}_{2} \mathrm{O}+\mathrm{s}\right)\end{array}$ & $\begin{array}{l}\text { Elec- } \\
\text { trieal } \\
\text { energy }\end{array}$ & $\begin{array}{l}\text { " } \mathrm{O}_{2}, \mathrm{~N}_{2} \\
\text { energy" }\end{array}$ & , "Tr. & $\underset{\mathrm{S}}{\text { Moles of }}$ & $\begin{array}{l}\text { Correc- } \\
\text { tion }^{1} \text { to } \\
25.00^{\circ} \mathrm{C} \text {. }\end{array}$ & $\mathrm{Q}, 25^{\circ} \mathrm{C}$. & $\begin{array}{l}\text { Devia- } \\
\text { tion } \\
\text { from the } \\
\text { mean }\end{array}$ \\
\hline 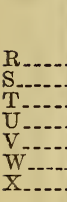 & $\begin{array}{l}{ }^{\circ} C . \\
25.50 \\
25.29 \\
25.35 \\
25.41 \\
25.49 \\
25.50 \\
25.48\end{array}$ & $\begin{array}{c}g \\
3,606.8 \\
3,595.8 \\
3,605.1 \\
3,609.0 \\
3,595.8 \\
3,587.8 \\
3,603.0\end{array}$ & $\begin{array}{c}\text { Int. } \\
\text { joules } /^{\circ} \\
15,399 \\
15,355 \\
15,393 \\
15,412 \\
15,357 \\
15,322 \\
15,386\end{array}$ & $\begin{array}{r}\text { Int. } \\
\text { joules } \\
4,689 \\
4,737 \\
4,703 \\
4,586 \\
4,597 \\
4,551 \\
4,705\end{array}$ & $\begin{array}{r}\text { Joules } \\
-17 \\
-22 \\
-22 \\
-6 \\
-14 \\
-11 \\
-13\end{array}$ & $\begin{array}{r}\text { Joules } \\
-6 \\
-8 \\
-8 \\
-12 \\
-12 \\
-11 \\
-13\end{array}$ & $\begin{array}{c}0.12215 \\
.14101 \\
.13257 \\
, 13591 \\
(.14930) \\
.14115 \\
.14069\end{array}$ & $\begin{array}{c}\text { Joules/ } \\
\text { mole } \\
-6 \\
-3 \\
-5 \\
-5 \\
-6 \\
-6 \\
-6\end{array}$ & \begin{tabular}{|c} 
Int.joules/ \\
mole \\
$+296,540$ \\
296,920 \\
296,900 \\
296,960 \\
$(295,930)$ \\
296,850 \\
296,730
\end{tabular} & $\begin{array}{r}\text { Joules } \\
-250 \\
+100 \\
+80 \\
+140 \\
+30 \\
-90\end{array}$ \\
\hline & & & & & & & & Mean & $+296,820$ & \pm 120 \\
\hline
\end{tabular}

1 See footnote to Table 3, p. 614 .

The results of the $\mathrm{SO}_{2}$ experiments are given in Tables 3 and 4 . Run $\mathrm{F}$ was lost. After run $\mathrm{H}$ was completed, some trouble developed in the oxygen line, but it was not until run $\mathrm{Q}$ was completed that the trouble was definitely located. The oxygen line was completely renovated, and then runs $R$ to $W$ were made. A time of one month elapsed between the two series of experiments. In calculating the average of the experiments, runs $\mathrm{D}$ and $\mathrm{V}$ were omitted as they are not in agreement with the others.

\section{RESULTS}

The results of the two series of $\mathrm{SO}_{2}$ experiments are:

\begin{tabular}{|c|c|c|}
\hline & Series I & Series II \\
\hline $\begin{array}{l}\text { Arithmetical average } 1 \text { of the series. } \\
\text { Average deviation from the mean } \\
\text { "Paximum deviation from the mean }\end{array}$ & $\begin{array}{r}296,730 \\
.061 \\
.108 \\
.022\end{array}$ & $\begin{array}{r}296,820 \\
.040 \\
.094 \\
.015\end{array}$ \\
\hline
\end{tabular}

1 The geometrical mean of the results is the same within 10 joules for the two series, while an average obtained by weighting the results according to the number of moles of $\mathrm{SO}_{2}$ formed leaves the average of the second series unchanged in the fifth figure and lowers that of the first series by 10 joules.

Because of the more proficient technic in the second series, as evidenced by the smaller deviations, the averages of the two series have been weighted inversely as the squares of their average deviations and the final "best value" taken as $+296,790$ international joules, with an average deviation from the mean of 0.047 per cent. 
The results of the calibration experiments (Table 1) showed an average deviation of 0.029 per cent. Since the value used for the heat capacity of the calorimeter plus $3,600 \mathrm{~g} \mathrm{H}_{2} \mathrm{O}$, enters into the calculation of $Q$, the heat of formation of $\mathrm{SO}_{2}$, the "best value" for $Q$ may be assigned a precision measure of

$$
\sqrt{(0.029 \text { per cent })^{2}+(0.047 \text { per cent })^{2}}=0.055 \text { per cent, }
$$

or 165 joules.

A conservative value for the possible error in the final result due to all known causes may be placed at \pm 200 joules, or 0.067 per cent.

The heat of formation of 1 mole of $\mathrm{SO}_{2}$, from gaseous oxygen and rhombic sulphur at $25^{\circ} \mathrm{C}$., is, then, $+296,790 \pm 200$ international

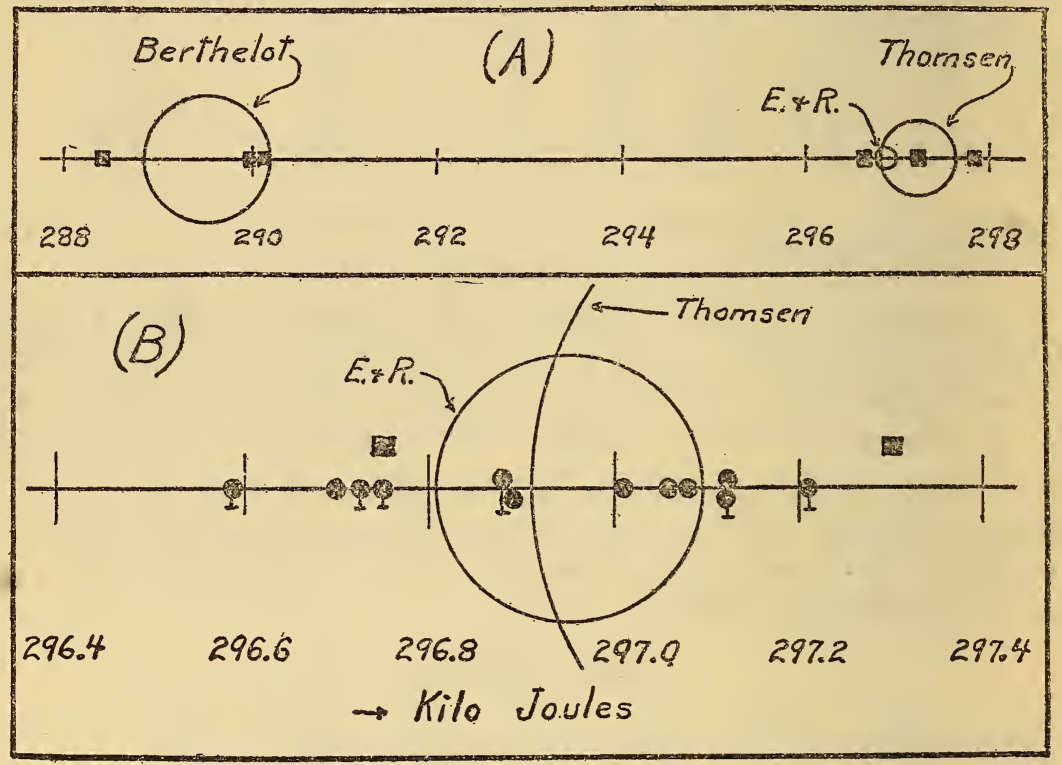

FigURE 8.-A graphical comparison of the data

joules; or, using the factor $1.00034,+296,890 \pm 200$ absolute joules. This latter value, divided by 4.185 , gives $+70,940 \pm 50$ g-cal.15.

In Figure $8(A)$, a comparison of these results with those of Thomsen. and of Berthelot is shown graphically. The circles are drawn in each case with a radius equal to the average deviation as reported by the investigators. The average values of Thomsen and Berthelot are, respectively, $+297,300$ and $+289,600$ joules per mole. ${ }^{15}$ The solid squares represent the three measurements of Thomsen and the three

15 In converting the results of Thomsen and of Berthelot from calories (about $18^{\circ} \mathrm{C}$.) to absolute joules, the factor 4.182 was used. Then, since their reactions were carried out at $16^{\circ}$ to $20^{\circ} \mathrm{C}$., the $\Delta C_{F}$ correction (Pt. VI, sec. 2) was applied. 
of Berthelot. The Thomsen circle almost completely incloses the E. and $R$. circle, showing that within the limits of his average deviation, the results obtained by Thomsen are in accord with those of the present investigation. Figure $8(B)$ shows an enlarged view of that portion of Figure $8(A)$ which contains the results of Thomsen and of $E$. and $R$. The small solid circles are the result of this work-the appendage identifying the results of Series $I$. The two solid squares are the two lowest of Thomsen's values.

Figure 9 shows a plot of the deviations of the various experiments as a function of the number of moles of sulphur converted to $\mathrm{SO}_{2}$ in

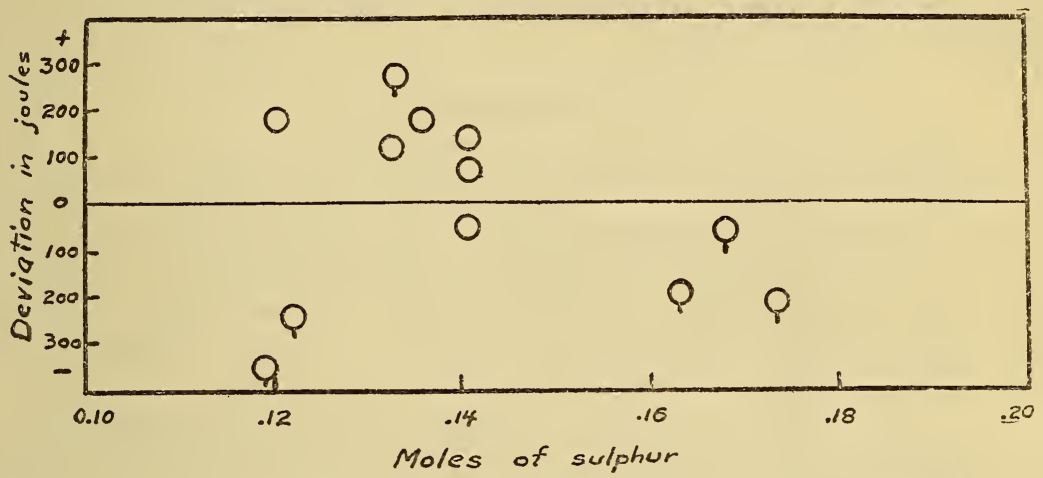

FIGURE 9.-A plot of the deviations as a function of the number of moles of sulphur in a given experiment

the given experiments. No trend of the deviation with the amount of sulphur is evidenced by this plot. The circles with appendages refer to the experiments of the first series.

$\mathrm{T}_{\triangle \mathrm{BLE}}$ 5.-Analysis of the measured quantities in the calibraition experiments

$$
C_{p\left(\text { ea lor. }+\mathrm{H}_{2} \mathrm{O}\right)}=\frac{E I Z \text { (O to } 4 \text { th m in.) })+E I Z \text { (frora 4th min. on })+ \text { “ } \mathrm{N}_{2} \text { energy" }}{\Delta t-U-K}
$$

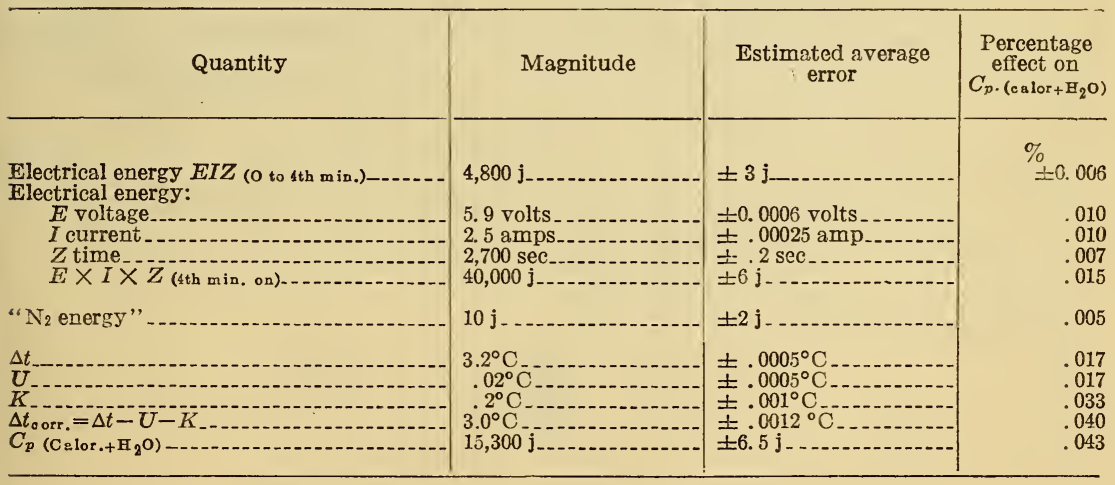

$69882^{\circ}-29-8$ 
Table 5 gives an analysis of the estimated average errors in the measured quantities of the calibration experiments. The resultant percentage error is the square root of the sum of the squares of the individual percentage errors. The error in measuring the mass of water in the calorimeter was negligible. The final estimated average error is slightly larger than the average deviation of the actual experiments as reported in Table 1. A like analysis for the sulphur experiments would be similar except that the second or main $E I Z$ term is omitted and the measurement of the mass of sulphur used up is included. The final estimated error of the sulphur runs was about equal to the average deviations of the experiments themselves as reported in Tables 3 and 4.

\section{SUMMARY}

The existing data on the heat of formation of $\mathrm{SO}_{2}$ are reviewed.

The problem of combining sulphur and oxygen to form $\mathrm{SO}_{2}$ with no $\mathrm{SO}_{3}$ was solved by the use of a special calorimetric reaction chamber in which oxygen was introduced into an excess of hot sulphur vapor. This reaction chamber and its method of operation are described in detail.

A complete description of the methods used in the chemical and the calorimetric control of this reaction and the procedure employed in recording and calculating the data are given.

The value obtained in this investigation for the heat of formation of one mole of gaseous $\mathrm{SO}_{2}$ from solid rhombic sulphur and gaseous oxygen at $25^{\circ} \mathrm{C}$. is $+296,890 \pm 200$ absolute joules, or $+70,940 \pm 50$ g-cal. ${ }_{15}$. This is compared with the results obtained by Berthelot and by Thomsen.

\section{ACKNOWLEDGMENTS}

The authors wish to express their gratitude to E. W. Washburn, under whose direction and guidance this investigation was carried out, and to acknowledge the aid received from E. F. Mueller in connection with the calorimetric apparatus and technic. Acknowledgment is also due to F. R. Bichowsky for his valued suggestions and continued incerest throughout the progress of this investigation. The authors are also indebted to the skill of E. O. Sperling for the construction of a satisfactory reaction chamber.

Washington, March 11, 1929. 